\title{
MODEL PENGUKURAN KUALITAS SITUS WEB PEMESANAN PIZZA ONLINE DI INDONESIA DENGAN METODE WEBQUAL DAN STRUCTURAL EQUATION MODEL (SEM)
}

\author{
Yulisa Gardenia \\ yulisagardenia@gmail.com
}

\begin{abstract}
ABSTRAK
Penelitian ini bertujuan untuk menganalisa pengaruh kualitas situs web terhadap loyalitas dan menganalisis pengaruh kepuasan pelanggan terhadap loyalitas. Objek penelitian yang dipilih adalah pengguna website Pizza Hut Delivery dan Dominos Pizza. Variabel yang digunakan dalam penelitian ini adalah variabel kualitas situs (webqual), kepuasan pelanggan (customer satisfaction) dan loyalitas pengguna (customer loyalty). Penelitian ini menggunakan quesioner dengan 250 responden. Analisis kualitas situs web pemesanan pizza online pada penelitian ini menggunakan Structural Equation Model dengan pengukuran menggunakan metode webqual. Hasil analisis pada pengujian hipotesis, menunjukkan bahwa website quality terbukti berpengaruh signifikan terhadap customer loyalty dan customer satisfaction terbukti berpengaruh terhadap customer loyalty.
\end{abstract}

Kata Kunci : Delivery Order, Website Quality (Webqual), Customer Satisfaction, Loyalty, SEM (Structural Equation Model)

\section{PENDAHULUAN}

Sejak restoran cepat saji mulai marak di Indonesia pada tahun 1990-an hingga saat ini, perusahaan makanan cepat saji di Indonesia selalu melakukan perubahan-perubahan untuk menyesuaikan perkembangan jaman. Mulai dari perubahan menu, pengemasan, hingga pelayanan yang diberikan oleh beberapa restoran cepat saji untuk bersaing di perekonomian yang global ini.

Saat ini, beberapa restoran cepat saji di Indonesia telah menunjukkan perubahan seiring dengan perubahan jaman dengan menyediakan layanan pemesanan secara online melalui situs web restoran tersebut, seperti contohnya Pizza Hut Delivery dan Dominos Pizza. Dengan hanya melakukan sekali registrasi di website restoran tersebut, data pribadi pelanggan akan tersimpan termasuk alamat pengiriman didalamnya sehingga ketika pelanggan ingin melakukan pemesanan berikutnya, pelanggan hanya perlu log in menggunakan akun mereka masing - masing. Seperti, www.phd.co.id untuk restoran Pizza Hut dan www.dominos.co.id untuk restoran Dominos Pizza. Pemesanan secara online dapat dilakukan melalui telepon seluler, komputer atau laptop konsumen.

Penerapan teknologi informasi terutama teknologi web sebagai media untuk mempromosikan produk-produk secara online serta dapat memudahkan pelanggan dalam memilih produk yang diinginkan oleh pelanggan merupakan pilihan yang tepat untuk menghadapi persaingan tersebut. 
Kualitas website akan sangat berpengaruh terhadap tingkat kepuasan penggunanya itu sendiri. Semakin tinggi kualitas suatu web, maka akan semakin banyak pengguna yang mengakses web tersebut (Risyad, 2011). Kepuasan pelanggan merupakan kunci dalam menciptakan loyalitas pelanggan. Banyak manfaat yang diterima oleh perusahaan dengan tercapainya tingkat kepuasan pelanggan yang tinggi, yakni selain dapat meningkatkan loyalitas pelanggan tapi juga dapat mencegah terjadinya perputaran pelanggan, mengurangi sensitivitas pelanggan terhadap harga, mengurangi biaya kegagalan pemasaran, mengurangi biaya operasi yang diakibatkan oleh meningkatnya jumlah pelanggan, meningkatkan efektivitas iklan, dan meningkatkan reputasi bisnis (Fornell, 1992).

Penelitian ini bertujuan untuk menganalisa pengaruh kualitas situs terhadap loyalitas dan pengaruh kepuasan pelanggan terhadap loyalitas.

\section{TINJAUAN PUSTAKA}

Webqual merupakan salah satu metode atau teknik pengukuran kualitas website berdasarkan persepsi pengguna akhir. Metode ini merupakan pengembangan dari Servqual yang banyak digunakan sebelumnya pada pengukuran kualitas jasa (Zeithaml, Parasuraman, dan Malhotra, Webqual sudah mulai dikembangkan sejak tahun 1998 dan telah mengalami beberapa interaksi dalam penyusunan dimensi dan butir pertanyaannya. Webqual disusun berdasarkan penelitian pada tiga area (dimensi) kualitas yaitu sebagai berikut

1. Dimensi Kemudahan Penggunaan (usability)

Usability adalah atribut kualitas yang menjelaskan atau mengukur seberapa mudah penggunaan suatu antar muka (interface). Kata "Usability" juga merujuk pada suatu metode untuk meningkatkan kemudahan pemakaian selama proses desain.

2. Dimensi Kualitas Informasi (information quality)

Kualitas Informasi tergantung dari tiga hal yaitu: informasi harus akurat, tepat waktu, dan relevan.

3. Dimensi Kualitas Interaksi (interaction quality)

Kualitas interaksi adalah sejauh mana system dapat berinteraksi kepada pengguna, baik organisasi atau pengguna lainnya, agar hubungan terhadap system dapat berjalan dengan terus menerus.

Structural Equation Model (SEM) merupakan teknik analisis yang memungkingkan pengujian sebuah rangkaian hubungan secara simultan. Hubungan ini dibangun antara satu atau beberapa variabel independen dengan satu atau beberapa variabel dependen. Masingmasing variabel dapat berbentuk faktor atau konstruk yang dibangun dari beberapa indikator. SEM merupakan pendekatan terintegrasi antara dua analisis yaitu analisis faktor dan jalur (path analysis). Lee (2007), mengemukakan structural equation models are well recognized as the most important statistical method to serve the above purpose and can be applied to many fields. SEM menggunakan metode statistik untuk menyajikan data dalam pencapaian tujuan penelitian dan dapat menerapkan banyak model dalam pencapaian tujuan penelitian dan dapat menerapkan banyak model dalam menjawab rumusan masalah penelitian.

\section{METODE PENELITIAN}

Dalam penelitian ini objek penelitian yang dipilih adalah pengguna 
website Pizza Hut Delivery dan Dominos Pizza di wilayah Jabodetabek. Metode penelitian yang digunakan adalah explonatory study yakni kaus kausalitas menjelaskan suatu hubungan antara variabel-variabel melalui pengujian hipotesis (Ghozali, 2004).

Ada tiga variabel yang digunakan dalam penelitian ini yaitu variabel kualitas situs (Webqual), kepuasan pengguna dan loyalitas pengguna. Selanjutnya untuk menentukan instrumen berdasarkan variabel penelitian dan kemudian menentukan sampel. Pengumpulan data dilakukan dengan metode observasi, wawancara dan kuisioner. Data yang terkumpul diolah dengan menggunakan alat analisis deskriptif dan kuantitatif. Teknik analisa yang dipergunakan untuk menganalisis data adalah analisis SEM (Structural Equation Model). Hasil analisa kemudian diinterpretasikan dan langkah terakhir disimpulkan serta diberikan saran. Untuk lebih jelasnya rancangan penelitian dapat dilihat pada Gambar 1.

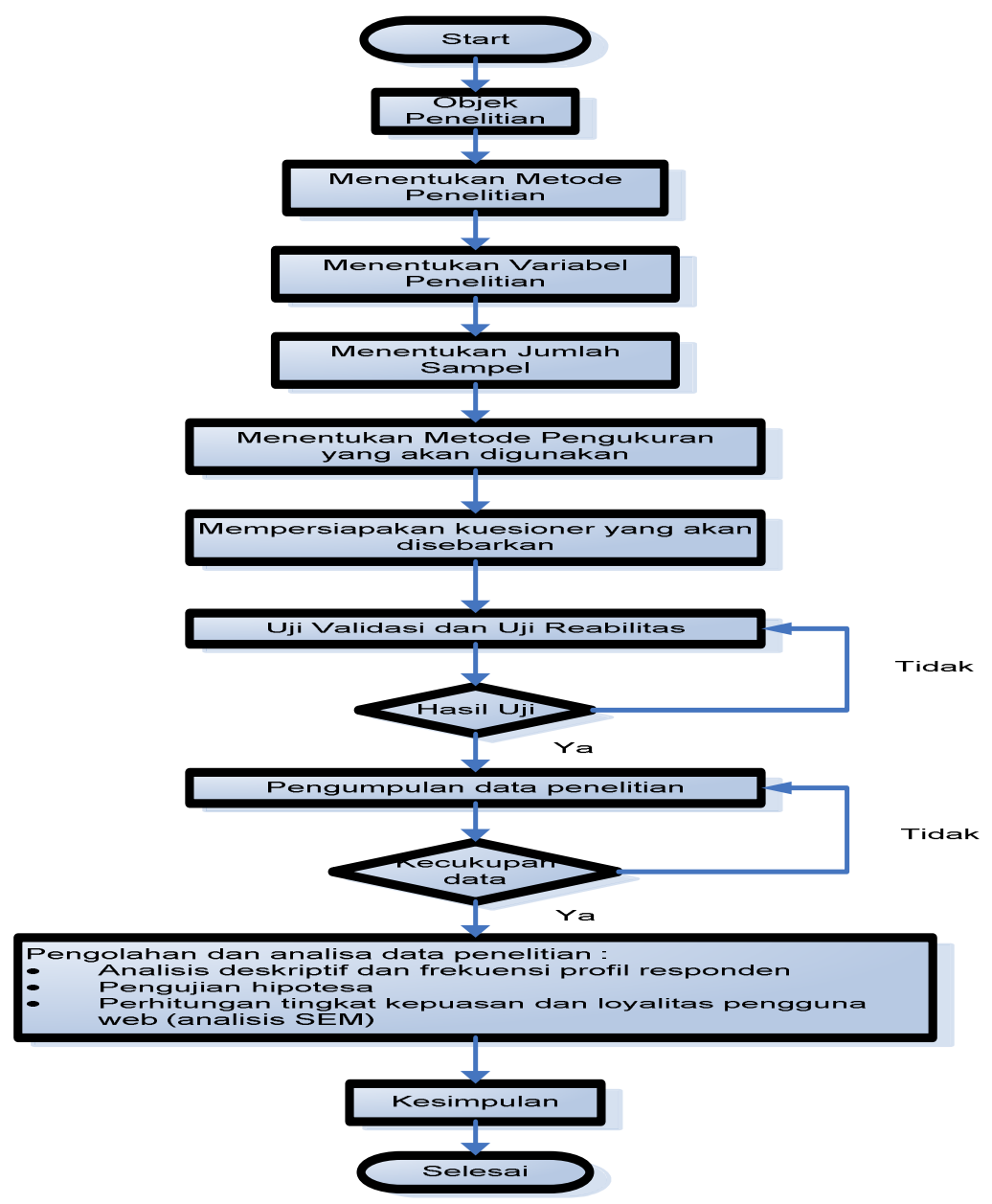

Gambar 1 Rancangan Penelitian 
Model SEM pada sampel penelitian ini dengan jumlah variabel laten (konstruk) sampai dengan lima buah, dan setiap konstruk di jelaskan oleh tiga atau lebih indikator, jumlah sampel 100-150 data sudah dianggap memadai (Santoso, 2014). Skala pengukuran yang digunakan pada penelitian ini menggunakan skala likert 5. Skala likert untuk penelitian ini memungkinkan untuk pengurutan data dari tingkat paling rendah ke tingkat paling tinggi. Penelitian ini, penulis menggunakan 5 kategori skala Likert yaitu Sangat Setuju (SS) dengan bobot penilaian 5, Setuju (S) dengan bobot penilaian 4, Netral (N) dengan bobot penilaian 3, Tidak Setuju (TS) dengan bobot penilaian 2 dan Sangat Tidak Setuju (STS) dengan bobot penilaian 1

Setelah itu dilakukan uji instrument untuk melihat validitas dan reabilitas kuesioner.

\section{HASIL DAN PEMBAHASAN}

Karakteristik responden bagian Identitas diri, membahas tentang identitas pelanggan berdasarkan jenis kelamin, usia, pendidikan dan pekerjaan.
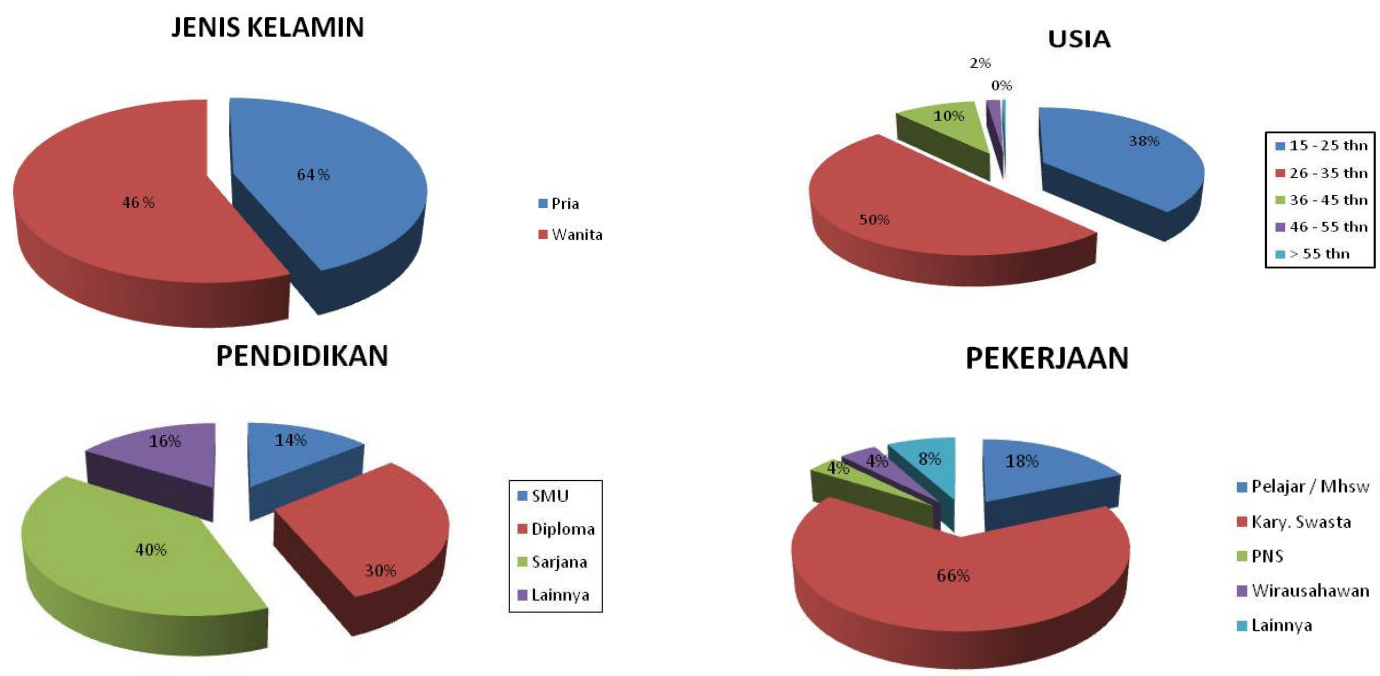

\section{Gambar 2 Karakteristik responden berdasarkan identitas diri}

Responden berjenis kelamin pria berjumlah 110 orang, sedangkan responden berjenis kelamin wanita berjumlah 140 orang. Dalam hal ini responden berjenis kelamin wanita lebih mendominasi dengan presentase sebesar $56 \%$ dibandingkan dengan responden berjenis kelamin pria yang hanya sebesar $44 \%$. Untuk usia diketahui bahwa sebanyak 95 orang dengan persentase $38 \%$ dari total 250 orang responden berusia 15-25 tahun, 126 orang responden dengan persentase
$50 \%$ berusia 26-35 tahun, 24 orang responden dengan persentase $10 \%$ berusia 36-45 tahun, 4 orang responden dengan persentase $2 \%$, dan sisanya 1 orang dengan persentase $0 \%$ berusia diatas 55 tahun. Sedangkan pendidikan dapat diketahui bahwa sebanyak 100 orang dengan persentase $40 \%$ dari total 250 orang responden berlatar belakang pendidikan Sarjana, 75 orang responden dengan persentase $30 \%$ berlatar belakang pendidikan terakhir Diploma, 40 orang 
responden dengan persentase $16 \%$ berlatar belakang pendidikan lainnya dan sisanya sebanyak 35 orang dengan persentase $14 \%$ memilih menjawab pendidikan lainnya. Dan berdasarkan pekerjaan dapat diketahui bahwa 164 orang dengan persentase $66 \%$ dari total 250 orang responden adalah karyawan swasta, 46 orang dengan persentase $18 \%$ berprofesi sebagai pelajar dan mahasiswa, 20 orang dengan persentase $8 \%$ dibidang lainnya, sementara sisanya

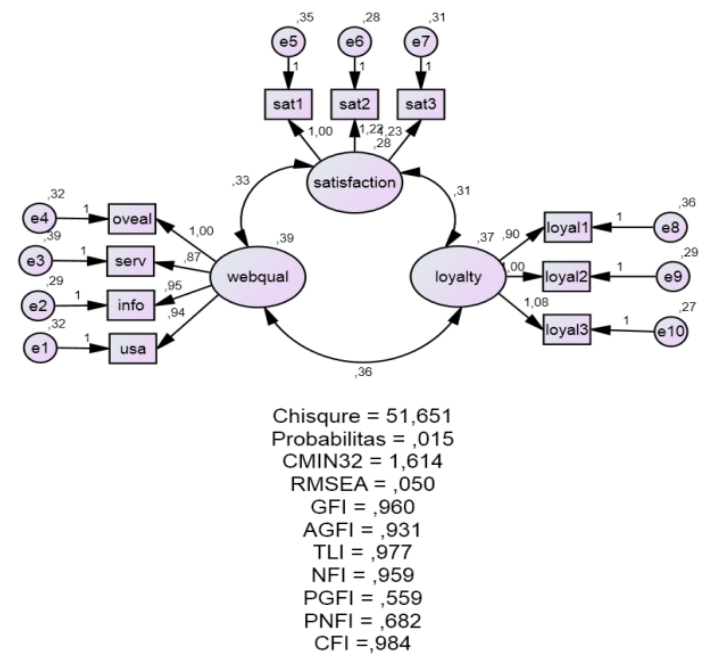

sebanyak 11 orang dan 9 orang dengan persentase $4 \%$ adalah Wirausahawan dan PNS.

Model yang baik sangat dipengaruhi oleh validitas indikator dan reabilitas konstruk. Oleh karena itu, perlu dilakukan pengujian terhadap validitas dan reabilitas (Nawangsari, Sugiarto, Natalisa, Amalia dan Prasetyo, 2013). Model analisis measurement dapat dilihat pada Gambar 3.

\begin{tabular}{|c|c|c|c|}
\hline Kriteria & Nlai Knitis & HasilModd & EvaluasiMode \\
\hline \multicolumn{4}{|l|}{ 1. Absolute Fit Indices } \\
\hline Gi-Square(CMN) & Dharakkankecil $\leq x^{2} \alpha, d f$ & 51,651 & Fit \\
\hline $\mathrm{DF}$ & & 32 & Fit \\
\hline Probability & $\geq 0,05$ & 0,15 & TidakFit \\
\hline $\begin{array}{l}\text { Ci-Square Relative } \\
\text { (CMNDF) }\end{array}$ & $\leq 2,00$ & 1,614 & Fit \\
\hline GH & $\geq 0,90$ & 0,960 & Fit \\
\hline RMSEA & $<0,08$ & 0,050 & Fit \\
\hline \multicolumn{4}{|c|}{2 Incrementd Fit Indices } \\
\hline ACH & $\geq 0,90$ & 0,931 & Fit \\
\hline TI & $\geq 0,95$ & 0,977 & Fit \\
\hline $\mathrm{NH}$ & $\geq 0,90$ & 0,959 & Fit \\
\hline $\mathrm{CH}$ & $\geq 0,95$ & 0,984 & Fit \\
\hline \multicolumn{4}{|c|}{ 3. Pansimnias Fit Indices } \\
\hline PNH & $>0,60$ & 0,682 & Fit \\
\hline PQH & $\geq 0,60$ & 0,559 & Moderat \\
\hline
\end{tabular}

\section{Gambar 3 Measurement Model}

Hasil perhitungan model SEM. Kriteria merupakan item, nilai kritis adalah hasil yang harus didapatkan dari setiap kriteria, hasil model merupakan hasil yang didapatkan dari gambar berdasarkan pengujian yang digunakan dan evauasi model merupakan pernyataan yang dibuat sesuai hasil model. Berdasarkan gambar 3, dapat dilihat bahwa hasil telah memenuhi kriteria goodness of fit dimana chi square menghasilkan hasil model yang sesuai dengan nilai kritis yang diharapkan maka evaluasi modelnya dinyatakan fit, sedangkan probability evaluasi modelnya dinyatakan tidak fit dikarenakan hasil model yang didaptkan dibawah dari nilai kritis yang diharapkan dan untuk kriteria PGFI hasil model hampir mendekati nilai kritis yang diharapkan maka dapat dikatakan evaluasi modelnya moderat. Menurut Solimun (2005) menyatakan jika ada satu atau lebih parameter yang telah fit maka model dinyatakan fit.

\section{Pengujian Validitas dan Reabilitas}

Setelah model dinyatakan fit, proses selanjutnya adalah melihat indikator yang ada pada sebuah konstruk. Proses ini dinamakan uji validitas konstruk (variabel laten) yang dilakukan lewat uji convergent validity yakni indi- 
kator yang menyusun sebuah konstruk mempunyai loading factor yang tinggi dengan konstruk tersebut dan total indikator akan mempunyai nilai variance extraced yang cukup tinggi dan Reliabilitas adalah ukuran internal

Tabel 1 Pengujian Validitas

\begin{tabular}{|c|c|c|c|}
\hline Konstruk & Indikator & $\begin{array}{l}\text { Loading } \\
\text { Factor }\end{array}$ & $\begin{array}{c}\text { Variance } \\
\text { Extracted }\end{array}$ \\
\hline \multirow[t]{4}{*}{ Webqual } & Usability & 0,721 & \multirow{4}{*}{0,513} \\
\hline & Information & 0,741 & \\
\hline & Service & 0,657 & \\
\hline & Overall & 0,742 & \\
\hline \multirow[t]{3}{*}{ Satisfaction } & Satisfactionl & 0,668 & \multirow{3}{*}{0,542} \\
\hline & Satisfaction2 & 0,774 & \\
\hline & Satisfaction 3 & 0,762 & \\
\hline \multirow[t]{3}{*}{ Loyalty } & Loyaltyl & 0,673 & \multirow{3}{*}{0,541} \\
\hline & Loyalty 2 & 0,748 & \\
\hline & Loyalty 3 & 0,781 & \\
\hline
\end{tabular}

Berdasarkan tabel 1 semua nilai loading factor indikator $>0,50$. Sehingga indikator-indikator yang dipakai dalam penelitian ini telah memenuhi syarat untuk menjadi indikator konstruk kualitas, kepuasan pelanggan dan loyalitas. Sedangkan, hasil variance extracted, menunjukkan angka minimal 0,5 yang menunjukkan adanya convergent validity yang baik. Nilai variance extracted yang tinggi menunjukkan bahwa indikatorindikator itu telah mewakili baik secara variabel bentukan yang dikembangkan.

Construct reliability di pada tabel 2 Pengujian Reabilitas diatas 0,70 menunjukkan reliabilitas yang baik. Berdasarkan hasil perhitungan tersebut, ka- consistency indikator dari suatu konstruk. Hasil reliabilitas yang tinggi memberikan keyakinan bahwa indikator individu semua konsisten dengan pengukurannya.

Tabel 2 Pengujian Reabilitas

\begin{tabular}{|c|c|}
\hline & Estimate S.E. C.R. P Label \\
\hline webqual 〈--〉 satisfaction & ,330, 044 7,564 **** \\
\hline loyalty 〈--〉 satisfaction & ,308, 041 7,441 **** \\
\hline webqual 〈--〉 loyalty & ,355, 045 $7,823 * * *$ \\
\hline
\end{tabular}

rena tidak ada nilai construct reliabiility yang nilainya di bawah 0,70 maka semua konstruk dalam penelitian ini layak digunakan dalam model.

Hasil dari pengujian pemodelan menunjukkan, model yang dibuat dapat disimpulkan telah teridentifikasi, dan hampir semua kriteria pemodelan telah terpenuhi. Model modifikasi tersebut dapat dilihat hampir keseluruhan data dengan indikator variabel baik variabel laten maupun varibel menifes dapat dikatakan sesuai. Tabel 3 Pengukuran Tingkat Kesesuaian (goodness-of-fitmodel) yang telah dilakukan Modifikasi SEM. 
Tabel 3 Pengukuran Tingkat Kesesuian (goodness of fit model)

\begin{tabular}{|c|c|c|c|}
\hline Kriteria & Nilai Kritis & Hasil Model & Evaluasi Model \\
\hline \multicolumn{4}{|l|}{ 1. Absolute Fit Indices } \\
\hline Chi-Square (CMIN) & Diharapkan kecil $\leq \mathrm{x}^{2} \alpha$;df & 40,677 & Fit \\
\hline DF & & 31 & Fit \\
\hline Probability & $\geq 0,05$ & 0,114 & Fit \\
\hline $\begin{array}{l}\text { Chi-Square Relative } \\
\text { (CMIN/DF) }\end{array}$ & $\leq 2,00$ & 1,312 & Fit \\
\hline GFI & $\geq 0,90$ & 0,969 & Fit \\
\hline RMSEA & $\leq 0,08$ & 0,035 & Fit \\
\hline \multicolumn{4}{|c|}{ 2. Incremental Fit Indices } \\
\hline AGFI & $\geq 0,90$ & 0,944 & Fit \\
\hline TLI & $\geq 0,95$ & 0,988 & Fit \\
\hline NFI & $\geq 0,90$ & 0,968 & Fit \\
\hline CFI & $\geq 0,95$ & 0,992 & Fit \\
\hline \multicolumn{4}{|c|}{ 3. Parsimonious Fit Indices } \\
\hline PNFI & $\geq 0,60$ & 0,667 & Fit \\
\hline PGFI & $>0,60$ & 0,546 & Moderet \\
\hline
\end{tabular}

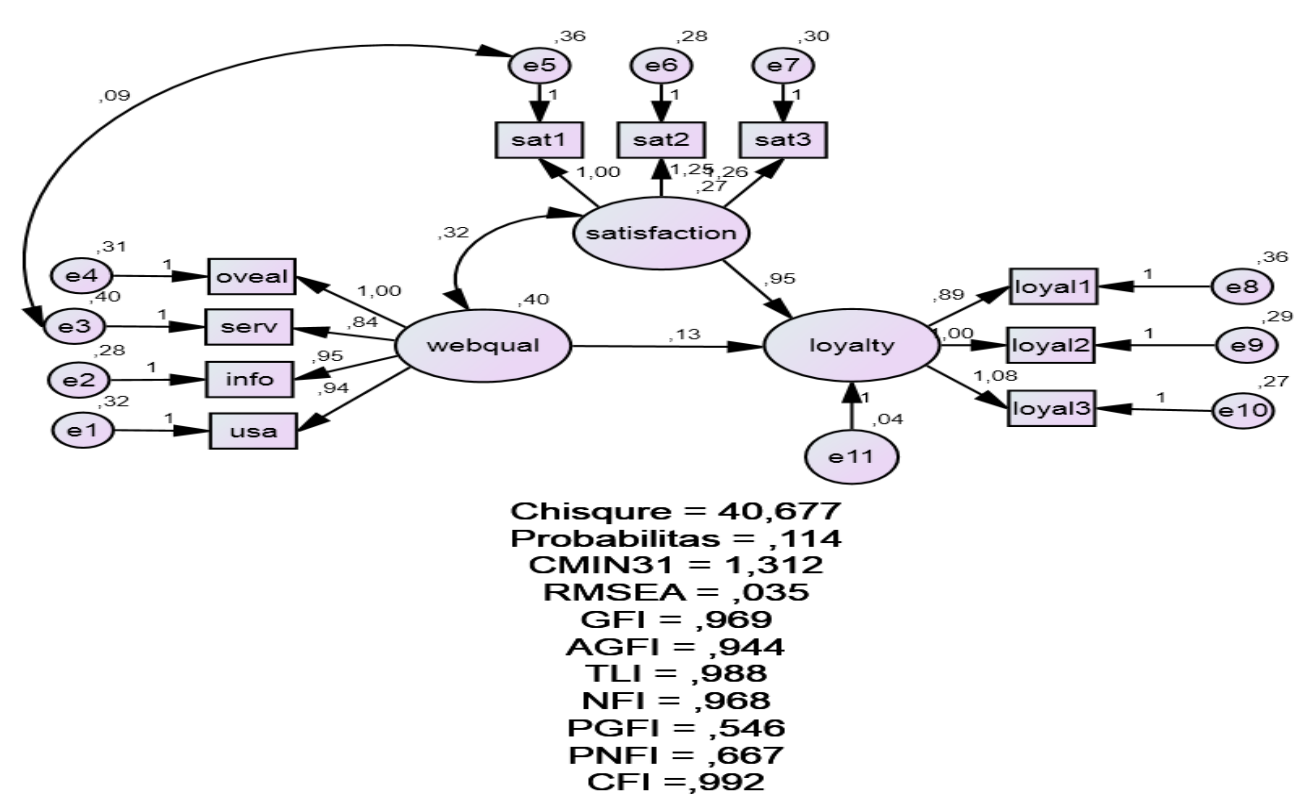

Model telah dilakukan pengujian, maka dapat dilakukan pengujian terhadap hipotesa. Dasar dalam pengambilan keputusan uji hipotesis dilakukan dengan membandingkan besarnya $p$ dengan level of significant sebesar $5 \%($ alpha $=0.05)$, jika $p$ kurang dari alpha tersebut maka hipotesis null $\left(\mathrm{H}_{0}\right)$ ditolak, serta jika $p$ besar dari alpha tersebut maka hipotesis null $\left(\mathrm{H}_{0}\right)$ diterima. Hasil dari Hipotesa dapat dilihat pada Tabel 4 Rangkuman Hasil Analisa Hipotesa dengan Metode SEM. 
Tabel 4 Rangkuman Hasil Analisa Hipotesa dengan Metode SEM

\begin{tabular}{|l|c|c|c|c|l|}
\hline \multicolumn{1}{|c|}{ Path Analysis } & Estimate & S.E. & C.R. & P & Keputusan \\
\hline $\begin{array}{l}\text { H1 } \\
\text { Loyalty } \leftarrow \text { Webqual }\end{array}$ & 0,130 & 0,840 & 0,155 & 0,877 & H1 Diterima \\
\hline $\begin{array}{l}\text { H2 } \\
\text { Loyalty } \leftarrow \text { Satisfaction }\end{array}$ & 0,949 & 1,019 & 0,931 & 0,352 & H2 Diterima \\
\hline
\end{tabular}

Data yang didapatkan pada tabel 4, yaitu nilai $p$ untuk hipotesis 1 (H1) sebesar 0,877 yang berarti signifikan, dengan demikian hipotesis 1 (H1) menyatakan bahwa situs kualitas situs terbukti berpengaruh terhadap customer loyalty.

Nilai $p$ untuk hipotesis $2(\mathrm{H} 2)$ sebesar 0,352 yang berarti signifikan, dengan demikian hipotesis $2(\mathrm{H} 2)$ menyatakan bahwa customer satisfaction terbukti berpengaruh terhadap customer loyalty.

\section{KESIMPULAN DAN SARAN}

Hasil dari penelitian dapat dibuktikan dari sebanyak 250 responden dengan jumlah 29 pertanyaan masingmasing hipotesa saling signifikan satu dengan lainnya.

Website quality terbukti berpengaruh signifikan terhadap customer loyalty. Hal ini dapat disimpulkan website pemesanan pizza online mampu membuat pelanggan yakin akan kualitas pemesanan pizza online, baik dalam segi keamanan, memberikan informasi dengan aman dsb, dikarenakan layanan yang diberikan restoran pizza menyediakan layanan yang berkualitas.

Customer satisfaction terbukti berpengaruh terhadap customer loyalty. Hal ini dapat disimpulkan layanan situs pemesanan pizza online mampu membuat pelanggan merasa puas secara keseluruhan terhadap layanan pemesanan pizza online sehingga pelanggan mempunyai pengaruh positif pada layanan, dan dapat mempertimbangkan jasa layanan restauran pizza merupakan pilihan pertama di bandingkan dengan layanan restauran lain yang memiliki situs pemesanan online.

Terlepas dari kontribusi yang diberikan penelitian ini, dalam rangka penyempurnaan lebih lanjut, khususnya terkait dengan metodologi penelitian. Saran yang diberikan oleh peneliti adalah penelitian ini menggunakan pemodelan Confirmatory Modelling Strategy yang digunakan pada measurement model dan structural model. Modifikasi model SEM dapat dilakukan pada model SEM di karenakan sebuah model yang 'lolos' uji tidak berarti bahwa model tersebut adalah model yang terbaik dari model-model alternatif lainnya. Penelitian akan lebih bagus jika dilakukan dua bentuk pemodelan lainnya yaitu pemodelan Competing Modelling Strategy dan pemodelan Model Development Strategy (Hair et al.(2006) dalam 'konsep dasar dan aplikasi SEM dengan AMOS 22' (Santoso, 2014). Sehingga nilai dari hasil uji menjadi lebih bagus seperti penurunan pada angka Chi Square, peningkatan angka GFI, dan sebagainya. 


\section{DAFTAR PUSTAKA}

Fornell, C. A National Customer Satisfaction Barometer: The Swedish Experience. Journal of Marketing. 1992.

Ghozali, Imam. Model Persamaan Struktur: Konsep dan Aplikasi dengan Program AMOS Ver.5.0, Badan Penerbit Universitas Dipenogoro, Semarang. 2004

Hair, J., Black, B., Babin, B., Anderson, R., \& Tatham, R. Multivariate data analysis. (6th ed). New Jersey: Prentice Hall. 2006

Nawangsari, Sri, Sugiarto, Toto, Natalisa, Diah, Amalia, Dina, dan Prasetyo, Eri. (2013). Analisis Korelasi Kualitas Web Terhadap Kepuasan Mahasiswa pada Salah Satu Perguruan Tinggi Swasta di Kopertis Wilayah Tiga. Seminar Nasional Aplikasi Teknologi Informasi (SNATI) Yogyakarta.
2013.

Santoso, S. Konsep Dasar dan Aplikasi SEM dengan AMOS 22, Elex Media Komputindo, Jakarta. 2014.

Wicaksono, Budi Luhur dan Susanto, Adhi. Evaluasi Kualitas Layanan Website Pusdiklat BPK RI Menggunakan Metode Webqual Modifikasian dan Importance Performance Analysis. JNTETI, Vol.2, No. 2. 2013.

Zeithaml, V.A., Berry, L.L., \& Parasuraman, A. The Behavioral Consequences of Service Quality. Journal of Marketing. 1996. 